\title{
THE FEMININE STYLE OF MANAGEMENT AND SUCCESS IN ORGANIZATIONS AS EXEMPLIFIED BY TECHNOLOGY STARTUPS
}

\author{
KOBIECY STYL ZARZĄDZANIA A SUKCESY ORGANIZACJI \\ NA PRZYKŁADZIE STARTUPÓW TECHNOLOGICZNYCH
}

https://doi.org/10.34739/zn.2020.54.05

\author{
Marek Makowiec \\ Poland, Cracow University of Economics, Institute of Management, \\ College of Management and Quality Sciences, Department of Organizational Behaviors \\ makowiec@uek.krakow.pl; ORCID: 0000-0002-3418-4771
}

JEL Classification Codes: M13

\begin{abstract}
The article contains considerations on the identification and verification of the impact of gender, and especially the feminine style of management on the success of an organization, with particular emphasis placed on technology startups. It presents examples confirming that women are better equipped to cope with problems in running this type of organization, as compared to men in the same positions. In the course of analysis, it was possible to identify the distinguishing features and characteristics of the female (modern) style of management in the context of startups.
\end{abstract}

Key words: management process, management, management styles, gender, male and female management style, technological startup

Streszczenie: W opracowaniu zawarte są rozważania dotyczące identyfikacji i weryfikacji wpływu płci, a szczególnie kobiecego stylu zarządzania na osiąganie sukcesów organizacji. Szczególny nacisk został położony na startupy technologiczne i pokazanie przykładów potwierdzających, że kobiety znacznie lepiej potrafią sobie radzić z problemami w prowadzeniu tego typu spółek - w zestawieniu z mężczyznami na takich samych stanowiskach. Prowadząc analizy udało się zidentyfikować wyróżniki i cechy charakterystyczne dla kobiecego (nowoczesnego) stylu zarządzania, w kontekście spółek technologicznych.

Słowa kluczowe: proces zarządzania, kierowanie, style zarządzania, płeć, męski i kobiecy styl zarządzania, startup technologiczny

\section{Introduction}

Managers are a group with a high level of responsibility for the overall functioning of the organization. Their supervising function allows them to have a direct impact on achieving the organization's goals and successes, both in the short- and long-term perspective. For the development of any organization, the right choice of managers, and the follow-up care for their professional development will be of utmost importance.

Nowadays, personality and gender perspective is often taken into account, both in scientific considerations and in business practice, so as to determine an employee's professional potential. In the case of an executive role, it is assumed that specific personality traits, desirable in a given organizational context, are crucial for the success of management actions. Modern organizations are increasingly paying attention to management styles and their stability, or at least predictability, in executive positions. In this case, the personality potential of the individual is identified, and attempts are made to predict the consequences of a person's behavior in the context of specific situations when they join their new team. In addition, other determinants that are relevant to the style of work and action are sought. One of these interesting variables is gender, which triggers considerations about the so-called feminine and masculine styles of management. This paper attempts to identify differences in masculine and feminine management styles in the context of technology startups. 
Currently, startup operations, as demonstrated by the experience of many countries, young and innovative enterprises, referred to as startups, impact the economy to a large degree, and thus are able to generate a high rate of economic growth. Various authors, researchers and business practitioners believe that such companies have a better chance of introducing radical innovations than mature enterprises.

Managing a successful startup is a very demanding task, primarily in terms of task diversity: from establishing investor relations, to delegating tasks, to analyzing various data and indicators. Combined with contextual thinking and a holistic vision for the company, the focus on cooperation, communication and networking can help a startup succeed in an uncertain business environment. The above features also characterize the so-called female management style.

\section{Research methodology}

Due to the inconsistency of the subject literature research results in terms of the relationship between gender and management, as well as its effectiveness, especially in the context of startups, the article is a review of both literature and findings. For this purpose, a query of the literature on the subject was conducted, as well as of the latest research reports on the conditions of startups' activities in Poland and abroad. Also, specific examples of technological startups run by women were indicated.

The latest research results from the years 2017-2019 were analyzed, a total of over 30 documents. Standard publications regarding the effectiveness of individual management styles and scientific articles on the discussed issues were also verified, over 40 publications in total.

Based on desk research, including literature studies of Polish and foreign literature that presents research results and reports on startups, management styles and their effectiveness, issues regarding diversity due to gender, general differences in women's and men's functioning in organizations, the author attempts to indicate the impact of the characteristics of female management style on achieving market success in the context of technological startups.

\section{Startup: definition and characteristics}

To quote various authors, it can be pointed out that a startup is a project phase or a company running a transition commercialization project until its operations are scaled to the needs of the mass market, or until it transforms into a mature organization (Sperczyński, 2014, p. 20). Łopusiewicz reports that a startup is a technological venture at the initial stage of development, created to solve the user's problem (Łopusiewicz, 2013, p. 8). In turn, Paul Graham, creator of $Y$ Combinator, one of the best known accelerators, claims that a startup is primarily a company, also a temporary one, characterized by its fast pace of development and focusing on finding the right business model for its venture (Łopusiewicz, 2013, p. 8). Similarly, Steve Blank, an entrepreneurship lecturer at such recognized universities as Berkeley, Columbia or Stanford, believes that the startup is defined as "an organization created to look for a repeatable and scalable business model" (Blank, 2010), whose goal is to achieve such a scalable business model that allows the acquisition of new markets and the development of the company in the assumed direction ("revenues, profit, number of users or clicks - to whatever the founders and investors have agreed" [ibid.]).

Currently, the number of startups in Poland is estimated at about 3,000. They operate mostly in the business-to-business (B2B) model, and the dominant segments are big data (19\%), analytics $(17 \%)$, IT (14\%), developer tools (14\%) and biotechnology (13\%). As many as $25 \%$ of startups are located in Warsaw, then in Wrocław, where the percentage is twice as low as in the capital (Łukoś, 2018).

It can certainly be said that being a startup entrepreneur is the result of very individual, independent and thoughtful decisions (Beauchamp, et al., 2018, p. 18). The latest report carried out by the Startup Poland Foundation in 2018, which surveyed as many as 806 Polish companies declaring as IT / ICT startups, shows that the main motivation of startups is neither money, nor external pressure, including that of the latest report carried out by the Startupfamily, which is characteristic of small businesses. What matters for startup founders is (ibidem):

a) desirable independence from a boss, job satisfaction,

b) flexible working time,

c) the ability to use your own competences and skills,

d) the opportunity to seize the perceived market opportunity,

e) running a business with people with a similar level of motivation,

f) the possibility of continuous development and learning,

g) the sense of agency that this form of organization provides. 
In considerations regarding startups, one should categorically pay attention to the extremely low market success rate, which is in a way a distinguishing feature of startups against the background of other types of businesses. As research shows, $92.9 \%$ of startups close within three years of winning a financial grant (Garczyńska-Szymkowiak, 2017).

The main reasons for the failure of the fledgling enterprises include too rapid development (even before developing a business model), the improper allocation of startup resources and market recognition (Klimek, 2017, p. 46), as well as, according to the author's observations, risky decisions on the part of the owners, sometimes a lack of rationality and, what is important - the overwhelming desire to stand out. This confirms in part that a startup management team should be characterized by specific features and approaches, because it is largely thanks to the management's decisions that the startup will survive, or disappear from the market.

The above findings indicate that the development of a startup as a specific organizational form, operating in conditions of extreme market uncertainty, requires an appropriate management style, different from that which is typical for traditional organizations. The dynamic market context of technology startups requires anticipating changes, and instant adaptation to new trends. It should be pointed out that the style of management in such businesses should be based on partnership and teamwork; quick, flexible response to changes, a positive attitude, the ability to combine and associate verbal and visual information, as well as a developed skill of reading of subtle signals, such as emotional voice tone, gestures and facial expressions, which can be particularly characteristic of the female management style.

In the context of startups, in which it is necessary to constantly search for the best ideas for the implementation of a product or service, and to constantly modify individual aspects of a business following dynamic changes in the environment, the feminine management style focused on partnership and cooperation as well as cooperation instead of competition will be highly recommended.

\section{Women in startups in Poland and abroad}

The activity of women as startup founders in Poland is declining, albeit slightly. Currently, 26\% of startups have a female founder (data for 2018) (Beauchamp et al., 2018, p. 19). In 2017, this ratio was higher among the total number of startup founders or co-founders, and amounted to $29 \%$. A year earlier, the percentage of women was $26 \%$, and in a 2015 survey, women constituted $28 \%$ of all startup founders (Hrywna, 2018).

The report Strong Women in IT 2019 on the situation of women in the IT industry in Poland indicates that women in Polish startups increasingly play managerial roles. In the Warsaw area they already constitute approx. $46 \%$, in Krakow 19\%, in Poznan 14\%, in Gdansk 12\%, and in Wroclaw $7 \%$. However, the authors point out that the situation is steadily improving with every year (Strong women in IT 2019). At the end of 2018, three female entrepreneurs from Poland were included on the list of American "Forbes" (Bellon, 2018) top 60 promising female-founded startups operating in the technology sector.

More and more initiatives of women from the startup industry are being developed in Western Europe, and their professional and startup activity is monitored by the project "Choose Possibility" (Singh, Cassidy, 2015). In turn, in the USA in the years 2009-2014 the percentage of startups created by at least one woman increased from $9.5 \%$ to almost $20 \%$. In New York, every fifth startup was founded by a woman (Balcerzak, 2017).

This does not change the fact that women are not a properly represented group in the context of startup management, both in Poland and abroad. The Boston Consulting Group examined the problem of attracting investors by analyzing the detailed data of the MassChallenge global network of entrepreneurship accelerators from the last five years in terms of funding received by 350 startups. 258 of them were founded by men and 92 were founded or co-founded by women. According to BCG analysts, female startups received a funding of USD 935,000 on average, i.e. Less than half of funding granted to men (their average was USD 2.1 million) (Akhmetova, Alhadeff, Green, Tracey, 2017). The author believes that it is due to the stereotype-based belief that women find it more difficult to function in business than men. These stereotypes are clearly debunked by the financial results of companies founded by women, which generated a $10 \%$ higher turnover within a five-year period than companies founded by men, an average of USD 730,000 compared to USD 662,000 (ibid.).

Based on the above data, it can be concluded that despite underrepresentation, women who are members of the decision-making group often take on a dominant role. The positive impact of women on the managed companies is supported by 
research. According to a study by the Peterson Institute, conducted with the support of EY, a $30 \%$ share of women in company boards increases the company's net profitability by up to $6 \%$. Diverse teams also have better results in logical analysis, coordination, planning and problem solving (Chomont, 2019).

In the 'Women Matter' report from 2018, the consulting company McKinsey revealed a strong correlation between the presence of women in top positions in companies and the better financial results the businesses achieve. After analyzing 300 companies from around the world, McKinsey identified a $47 \%$ difference in return on equity between companies with women in the majority in the executive bodies and those without them, and a $55 \%$ difference in operating profits (Devillard, Kossoff, Sancier-Sultan, de Zelicourt, 2016).

The vast majority of enterprises surveyed in the report operated in the advanced technologies area, industry and IT, therefore their results can be considered as contributing to an analysis of the functioning of startups.

The report "The State of European Tech" (The 2018 State of European Tech Report is Live. The largest and most comprehensive dataset of European tech is back, 2018) states that men have a strong numerical advantage on the boards of technology startups. Report prepared in 2018 by a London-based venture capital management company Atomico, in cooperation with Orrick consulting company and a global Finnish organizer of startup meetings, Slush (ibid.). According to its authors, 93\% of USD 23 billion invested in European technology startups in 2018 (almost five times more than five years earlier) went to companies founded only by men. In turn, nearly $90 \%$ of the surveyed founders of technology startups, as well as their investors and employees declared that a gender-diversified team is nothing but beneficial for a startup. The data from the study shows how huge are the challenges related to the professional discrimination of women that the technology industry from the Old Continent and the entire ecosystem of local startups face (ibid.).

\section{Female-founded startups: examples of market successes}

When analyzing specific examples of successful startup ventures in Poland and around the world, it is necessary to point out a few very interesting cases, in which the idea itself and the growth of the company was possible thanks to women.
Selected examples of successful female startup founders from outside of Poland:

a) Zola portal enables newlyweds-to-be to prepare for their wedding and provide their guests with a list of their dream wedding gifts, at the same time making it easier for the guests to make a purchase directly via the platform. Zola obtained over USD 15 million in three rounds of financing and became a comprehensive platform for wedding planning and logistics services (Balcerzak, 2017). Zola's founder, Shan-Lyn Ma had built her career as product manager in the lifestyle industry.

b) Shoptiques

(https://www.shoptiques.com/about-us)

An online marketplace that allows users to buy clothes, shoes and accessories from over 5,000 exclusive boutiques in 35 countries around the world. Shoptiques was already on the list of the most promising startups according to Forbes in 2015. Olga Vidiseva, the founder, gained her professional experience e.g. at Goldman Sachs. Her business idea was born out of an unsatisfactory shopping experience in high-end boutiques.

c) The RealReal is an online ecommerce portal for pre-owned luxury and high-end designer goods, which raised USD 115 million at the end of 2018. The RealReal has a strict and lengthy process to ensure fakes never make it onto the site. The founder, Julie Wainwright, was inspired by watching a friend spend " $\$ 5,000$ in 20 minutes" (Wainwright, 2019).

d) ClassPass provides subscriptions to various sports and fitness classes, which raised USD 85 million of financing. After being unable to easily find a dance class in New York City, the founder, Payal Kadakia, a dancer and performer herself, set out to create a platform that would make finding and booking fitness classes easier than ever before (Winn, 2019).

e) Guild Education. Guild co-founders Rachel Romer Carlson and Brittany Stich spent their early careers working at the intersection of education and technology, helping community college students succeed in school through tech-enabled coaching and navigate the process to transfer to a four-year school. Their startup helps companies offer education as a benefit to their employees, creating a corporate $\mathrm{ROI}$ while helping employees advance their education and career (Sukin, 2018). In early 2019, the startup acquired USD 40 million (Ciesielski, 2018). 
Selected examples of successful female startup founders from Poland:

a) Moiseum

A company that provides creative projects for museums and cultural institutions, focusing on the latest technologies. The founder, Zuzanna Stańska created the DailyArt mobile application, recognized by The Next Web as one of the 12 best educational applications of 2012. She is the author of a blog on technologies used in museums (Kaźmierczak, 2019 and http://www.moiseum.com/\#.services).

b) Azimo (https://azimo.com/pl)

A platform cooperating with the largest payment operators in the world, delivering quick money transfers to over 60 countries around the world. It accepts most of the world's currencies, which allows making instant transfers to a specific account. New countries are systematically joining the platform and the area of operation is significantly expanding. The platform was co-created by a Pole (Marta Krupińska).

c) Deko Eko (https://dekoeko.com/)

It is a unique Europe-wide sales and community platform that consolidates and develops the market for upcycled and organic products. Currently, the platform cooperates with over 200 designers, artists and producers creating materials from recycled or ecological materials. Deko Eko also offers comprehensive support for organizations in developing innovative solutions for creative upcycling, recycling and eco-marketing as part of the proprietary offer "Brand Upcycling". The founder, Agata Frankiewicz, has years of experience as a brand manager, having worked with dozens of recognized brands in advertising agencies in Krakow and Warsaw.

d) Vouchery.io (https://www.vouchery.io/)

This German startup is headquartered in Berlin, the startup has created a platform for generating and managing personalized discount coupons for customers, facilitating the optimization of marketing expenses. The founder, Ewelina Robaczek was Product \& Business Owner in the marketplace industry and dealt with personalizing customer experience in real time. She is also the founder of the Project Przedsiębiorcza Kobieta (Enterprising Woman) dedicated to empowering young female graduates.

e) PRowly (https://prowly.com/pl/)

A comprehensive platform solution for people managing the image and communication of a brand. PRowly enables an intuitive and functional way to present corporate content in an interactive way; and thanks to the analytical module it facilitates the optimization of media relations activities. The founder, Joanna Drabent, is herself a PR specialist.

f) Evenea (https://evenea.pl/pl)

Online ticket sales platform, offering promotion and coordination features for the organizers. The founder, Agnieszka Oleszczuk-Widawska, was encouraged by the success of the American portal Eventbrite.com on her trip to the USA.

g) Gastronauci.pl/FoodForward

Gastronauci.pl was a website and mobile app presenting user-rated dining options available in a given location, from gourmet restaurants, to lunch bars, to street food. The solution used geolocation to point users to venues that match the search parameters. The founder, Aleksandra Lazar, is a foodie and culinary critic. Her business idea was inspired by foreign portals presenting available dining options in a clear and timely manner. Her portal was sold to Zomato, and now she is working on a food tech accelerator, FoodForward (Balcerzak, 2017 and Bellon, 2019).

In the context of female-founded startups, one should also mention Female Founders Poland, a startup founded by Magdalena Olczak in 2016 in response to a need for an environment for entrepreneurial women to exchange their experiences and learn from each other. Initially, Female Founders Poland was only a Facebook group for the founders of technology startups. Currently, it brings together women from across the industry who want to develop professionally, network and exchange experiences. The group aims to introduce good practices to the industry, including battling the stereotype of female envy. Women are characterized by mutual jealousy (more: https://www.female-founders.org/).

\section{Feminine and masculine management style and their efficiency in technology companies}

Researchers indicate that personality can be one of the strongest factors differentiating a management style (Hogan, Kaiser, 2010, p. 8687). Moreover, "having certain personality traits or lack thereof, can determine failure when it comes to managing people and managing an enterprise" (Kraczla 2017, p. 46). Therefore, it can be hypothesized that gender may be a significant source of the effectiveness or inefficiency of actions taken in the management role (more in: Kraczla, 2017, p. 47). However, most of the 
research on individual entrepreneurship and technology companies focuses on men. Unfortunately, this often results in falsifying the image of the entrepreneur.

Female presidents and board members behave differently than men in their relations with subordinates and colleagues. Based on a literature review, it can be determined that the management style of women is distinguished by natural multitasking, a lesser willingness to compete than in men and greater emphasis on building relationships, which translates into building organizations more suited to the needs of modern times (Piasecka, 2019, p. 17). Women consult and enjoy inspiring their team, appealing to rational justification, which they use more often than men in top positions (Dźwigoł-Barosz, 2016, p. 132).

The feminine style of management emphasizes agreement, and encourages mutual respect and kindness. Such an approach builds fruitful and long-term cooperation with clients (Responsible Partnership, 2017-2018, R 9). Women often focus on cooperation and development of the entire team, willingly sharing knowledge and supporting other team members. This creates a synergy that increases efficiency, ingenuity, quality of work; and ultimately, builds the company's position. Usually, women also make wise decisions, which are balanced, and relevant to the given moment in time (Overcoming Difficulties, 2017-2018, R 11). It also seems that women are usually more perceptive, are guided by intuition, and are capable of interpreting various signals coming from the environment. Albeit afraid of risk at times, they always try to minimize the same, which is a positive feature in business practice as it reduces the unpredictability of actions.

Women's success in business stems from their combining knowledge, education and skills with specific psychological features: the ability to combine and associate verbal and visual information, reading subtle signals, e.g. The emotional tone of voice, gestures and facial expressions, as well as openness to the client or readiness to work hard (Sarri, Trihopoulou, 2005, pp. 24-36). In addition, women are more willing to develop educationally, and are open to change. These are the skills that are very much needed in the new economy (Lisowska, 2009, p. 112).

The development of ICT technologies, networking of economies and globalization force managers to take into account the increasing number of factors in making management decisions. In this process, a very helpful characteristic is holistic thinking, which is more natural for women and which can be acquired by men (Lisowska, 2009, p. 112). What is more, research confirms that women often focus on creativity; whereas men focus on competition (France-Massin, 2019). After examining ten-year data from 300 companies, the First Round Capital fund pointed out that startups with at least one woman in management navigate the market $63 \%$ better than men-only teams (Hrywna, 2018).

Upon observing and identifying the differences in managing organizations by men and women, it should be pointed out that people representing the male style of management are unwilling to share power. They give specific orders and expect them to be carried out. They are taskoriented, and usually care little about relations with subordinates. They are competitive, often pressuring, wanting to be the best and infallible. Feminine management style is based on diligence, communication, partnership, establishing close relations with subordinates, rational justification of one's decisions, as well as showing understanding and empathy for colleagues. It should be emphasized that these features depend not only on gender, but also on the personality and temperament of those responsible for management, as well as on their position level.

Research carried out in Poland on a group of managers representing mixed sectors of enterprises (Moczydłowska, 2017, p. 19) showed that a woman in a managerial position is most often perceived as diligent, emotional, and as someone who harnesses a good atmosphere in the workplace. At the same time, the respondents attributed two characteristics to women in managerial positions: ambition and a high level of expectation for themselves and their subordinates, with simultaneous respect for them. The research also showed that the male manager is stereotypically perceived as a "strong man", "macho" and a charismatic leader. In the opinion of the respondents, he is: determined, demanding, responsible, authoritarian, ambitious, but also often not objective. He is characterized by selfconfidence and a strong rooting in vision. In turn, he expects boundless trust from his subordinates, has a tendency to manipulate others, and retains a competitive attitude and emotional resilience. At the same time, he shows little tolerance and empathy, and avoids the use of intuition in the decision-making process. The respondents also indicated that the male manager has poor listening skills and that he is rarely interested in the opinions of his subordinates (ibid.). 
Features typical for the traditional (so-called male) management style in combination with the modern (so-called female) features (perceived as being desirable for startups), was prepared based on both the results of analyzed research and the report "Strong Women in IT" 2019, are presented in Table 1.

Table 1. Features typical of traditional (male) and female management style in the context of startups

\begin{tabular}{l|l}
\hline \multicolumn{1}{c|}{ Masculine style (traditional) } & \multicolumn{1}{c}{ Feminine style (modern) } \\
\hline Fear-based management & Kindness-based management \\
\hline $\begin{array}{l}\text { Distance and hierarchical superior-subordinate } \\
\text { relationships }\end{array}$ & Partner relations with subordinates \\
\hline Focus on forcing one's reasons & Focus on compromise and mediation \\
\hline Sufficient level of qualifications and experience & High qualifications and extensive experience \\
\hline Thinking in terms of ideas & $\begin{array}{l}\text { Thinking in terms of people's good, generating } \\
\text { synergistic effects thanks to interaction and } \\
\text { cooperation }\end{array}$ \\
\hline Determination in achieving the goal & Materiality and efficiency to the limit of compromise \\
\hline $\begin{array}{l}\text { Tendency to underestimate the human factor } \\
\text { Little emotional intelligence }\end{array}$ & $\begin{array}{l}\text { Respect and respect for subordinates and partners, } \\
\text { focus on communication and interpersonal skills }\end{array}$ \\
\hline $\begin{array}{l}\text { Problems with effective motivation of the } \\
\text { subordinates }\end{array}$ & $\begin{array}{l}\text { High emotional intelligence } \\
\text { Ease of effective motivation of the subordinates }\end{array}$ \\
\hline Difficulties in transferring one's competence to others & $\begin{array}{l}\text { Ease of sharing knowledge through mentoring and } \\
\text { coaching }\end{array}$ \\
\hline Focus on competition and control & Focus on cooperation and teamwork \\
\hline Autocracy based on directives & Democracy based on participation \\
\hline Plan- and strategy-based management & Quick response to changes \\
\hline $\begin{array}{l}\text { Formal arrangements in the context of customer } \\
\text { offers }\end{array}$ & $\begin{array}{l}\text { Constant cooperation with the client and taking into } \\
\text { account their expectations }\end{array}$ \\
\hline $\begin{array}{l}\text { Decision-making processes based on extensive } \\
\text { documentation collected in a traditional way }\end{array}$ & $\begin{array}{l}\text { Decision-making processes supported by professional } \\
\text { tools and expert software }\end{array}$ \\
\hline
\end{tabular}

Source: own elaboration based on: (Brol, Kosior, 2004: 10, In: Lisowska, 2009: 118; Report: „Strong Women in IT” 2019).

To sum up the differences presented in the table between the two management styles, and taking into account the changes that have occurred in the modern economy, it seems more desirable to use a female management style in the context of startup management as it attaches less importance to hierarchy, and more to teamwork. Moreover, a knowledge-based economy requires managers to have more skills from the catalog of the so-called female management style, e.g. empathy, ability to communicate in a diverse team, cooperation and teamwork, win-win negotiating skills, flexibility and openness to frequent changes.

The aspects analyzed in this study support the results of research under the project implemented in the period of January - July 2019 by the University of Social Sciences and Humanities in Warsaw, together with the Infoshare Foundation (Kania, Trapp, 2019). The study involved 91 CEOs of startups, 50 men and 41 women, of which the largest group were people in the $30-40$ age range (49 people). The study illustrates that a successful startup can be run by both a male and female CEO. After careful analysis of the report and the success factors of the surveyed CEOs, it can be concluded, however, that women demonstrate more features listed in the study, which belong to the catalog related to the female style of management (ibid.):

- a higher level of grit, understood as tenacity and passion in pursuit of long-term goals and a tendency to achieve long-term goals with hard work and persistent enthusiasm,

- a higher level of passion, understood as longterm consistency,

- a higher level of perseverance, understood as the ability to work for a long time, even in the face of adversity or failure,

- high expectations of the results of own actions, conviction of one's agency, knowledge and skills that will help to implement the adopted action plan,

- a greater action orientation and better coping with failures, resistance to collapses, the ability to quickly get back on track and continue activities leading to the set goal, 
- a greater emotional stability, i.e. a major need for autonomy, independence and high emotional adaptation,

- a greater diligence, i.e. efficiency, organization and regularity of action,

- a greater amenability, i.e. willingness to cooperate and a generally positive attitude towards people.

The analyzed data indicates that CEOs of such a specific group as startups should work on developing their so-called female management style, because they can be constantly worked on and improved, regardless of natural inclinations.

\section{Conclusions}

In the course of the research, the characteristics and features of the female style of management in modern enterprises and startups were identified. The analysis and verification of the cited studies confirms that gender issues are important in the context of managing technological organizations and that women have all the attributes of an effective startup manager. The features presented above certainly do not exhaust the list of all the qualities of an effective manager, but their proper identification will definitely affect the entrepreneurial mindset. The quoted research results, specific examples of successful female startup founders, and the observation of the laws of the labor market in the context of business activity, especially the running of technology startups, confirms that the female style of management is characterized by many attitudes that are valuable for modern organizations striving to operate in an efficient, yet flexible way.

In any discussion on women's management style, the issue that must be mentioned is the popular myths about women: their lesser degree of availability and effectiveness; their emotional reactions, timidity and lower self-confidence; their lesser focus on competition, domination, success and promotion, tolerance of a lower salary, lesser degree of knowledge, skills and experience in managing and visualizing the future than men (Kupczyk, 2009, p. 29). The stereotypical perception of women in Poland is slowly changing; as demonstrated by the research carried out by PARP, the situation of women in managerial positions on the domestic labor market looks best in the group of managers ( $47 \%$ of the population). In contrast, in senior management groups and board members, women constitute $13 \%$ and $21 \%$ respectively (The Job Market, Education, Competence. Current Trends and Research Results, 2019).
The results of research by Deloitte (Frańczak, Georgijew, 2012), as well as many other analyzes, indicate that a lack of understanding as to the benefits of female participation in management also has a huge impact on the weak position of women in company management.

Regardless of whether the manager is a woman or a man, persons in managerial positions should constantly develop their managerial skills and flexibly apply various strategies, which are effective in a given situation. Efficiency is a skill that can be learned. The management style that is more often the natural style of women is undoubtedly that which is more socially and business-effective. Its importance in the functioning of not only businesses, but also various types of non-profit organizations, should be systematically increased.

\section{Acknowledgement}

The paper was financed with subsidies granted to the Faculty of Management of the Cracow University of Economics for maintaining the research capacity.

\section{References}

Akhmetova, Z., Alhadeff, M., Green, A., Tracey, C. (2017). What's Working to Drive Gender Diversity in Leadership. BCG The Boston Consulting Group. Retrieved from: http://imagesrc.bcg.com/Images/BCG-Whats-Working_ tcm87-155374.pdf.

Balcerzak, A. (2017). Kobiety w startupach technologicznych [Women in technological startups]. Retrieved from: https://marketingibiznes.pl/it/ kobiety-startupach-technologicznych/.

Beauchamp, M., Krysztofiak-Szopa, J., Ociepka, T., Skala, A. (2018). Polskie Startupy Raport 2018. [Polish Startups, Report 2018]. Warsaw: Startup Poland Foundation.

Bellon, M. (2018). Trzy Polki na liście założycielek najbardziej obiecujących startupów według "Forbesa". [Three Polish women on a list of the most promising startups according to "Forbes"]. Retrieved from: https://businessinsider.com.pl/ technologie/polskie-startupy-zalozone-przezkobiety-na-liscie-forbesa/jc616yf.

Bellon, M. (2019). Założyła "Gastronautów”, teraz startuje $z$ akceleratorem dla tych, którzy chca zrewolucjonizować branżę spożywczą. [She established "Gastronauci" and now wants to start with accelerator for those who want to revolutionize the grocery sector]. Retrieved from: https://businessinsider.com.pl/technologie/nowetechnologie/ola-lazar-tworczyni-gastronauciplstartuje-z-foodtechowym-akcleratorem/kyv6ym5. 
Blank, S. (2010). What's A Startup? First Principles. Retrieved from: http://steveblank. com/2010/01/25/whats-a-startup-first-principles.

Brol, J., Kosior, M. (2004). Kobiecy styl zarządzania w Polsce (aspekty społecznoekonomiczne). [Women's Style of Management in Poland (socioeconomic aspects)]. Kobieta i Biznes (1-4).

Chomont, M. (2019). Kobiety w VC-różnorodność daje lepsze wyniki. [Women in VC - Diversity Gets Better Results]. Retrieved from: https://www.doradcawbiznesie.pl/kobiety-w-vcroznorodnosc-daje-lepsze-wyniki.

Ciesielski, M. (2018). "Męski startup" dostaje 2,1 mln USD od inwestorów, a kobiecy mniej niż $1 \mathrm{mln}$ USD. Inwestorzy wolą facetów. [Masculine Startup Obtains 2,1 mln \$ from Investors, while Feminine Less Than $1 \mathrm{mln}$ \$. Investors Prefer Men]. Retrieved from: https://fintek.pl/startupyprowadzone-przez-kobiety-niedoinwestowaneale-bardziej-efektywne/.

Devillard, S., Kossoff, C., Sancier-Sultan, S., de Zelicourt, A. (2016). Women Matter 2016 Reinventing the workplace to unlock the potential of gender diversity. McKinsey\&Company. Retrieved from: https://www.mckinsey.com/ $\sim /$ media/mckinsey/featured\%20insights/women $\% 20$ matter/reinventing\%20the\%20workplace\%2 Ofor\%20greater\%20gender\%20diversity/womenmatter-2016-reinventing-the-workplace-tounlock-the-potential-of-gender-diversity.ashx.

Dźwigoł-Barosz, M. (2016). Wpływ kobiet na biznes. [Women in business]. Gliwice: Zeszyty Naukowe Politechniki Śląskiej. Organizacja i Zarządzanie (93).

France-Massin, D. (2019). Women in leadership bring better business performance. Retrieved from: https://www.ilo.org/global/about-the-ilo/ newsroom/news/WCMS_701767/langen/index. htm.

Frańczak, H., Georgijew, I. (2012). Kobiety i władza $w$ biznesie [Women and Power in Business], Warsaw: Deloitte, Thinktank.

Garczyńska-Szymkowiak, L. (2017). Dlaczego startupy upadają? [Why do startups go Bankrupt]. Retrieved from: https://www.zafirmowani.pl/ artykuly-i-wideo/zakladanie-dzialalnosci/ dlaczego-startupy-upadaja.

Hogan, J., Kaiser, R.B. (2010). Personality. In: J.C. Scott, D.H. Reynolds (Eds.). Handbook of Workplace Assessment, Organizational Studies, Jossey-Bass, San Francisco, 81-108.

Hrywna, I. (2018). Jeśli kobieta chce, może wszystko. [If Woman Wants, She Could Do Anything]. Retrieved from: http://gazeta olsztynska.pl/523451, Jesli-kobieta-chce-mozewszystko.html.
Kania, J., Trapp, A. (2019). Determinanty sukcesu CEO startupów [Startup CEO Success Determinants], Warsaw: Uniwersytet SWPS. Retrieved from: https://infoshare.pl/global_ceo_ research/Wyniki_raportu_Determintanty_sukces u_CEO_startup\% $\%$ C3\%B3w_13062019.pdf.

Kaźmierczak, A. (2019). Kobiety na startupy [Women for startups]. Retrieved from: https://magazynterazpolska.pl/pl/a/kobiety-nastartupy.

Klimek, J. (2017). W sektorze MSP - Refleksje o zarządzaniu przedsiębiorstwem innowacyjnym. [In the SME Sector - Reflections on managing an innovative enterprise], In: A. Kałowski, J. Wysocki (eds.). Startup a uwarunkowania sukcesu. Wymiar teoretyczno-praktyczny. [Startups and the Determinants of Success. Theoretical and Practical Dimensions]. Warsaw: Oficyna Wydawnicza SGH, SGH Warsaw School of Economics.

Kraczla, M. (2017). Kobiecy a męski styl kierowania w kontekście różnic osobowościowych. [Female and Male Management Style in the Context of Personality Differences]. Przegląd Organizacji (9), 46-52.

Kupczyk, T. (2009). Kobiety w zarządzaniu i czynniki ich sukcesów [Women in Management and the Factors Behind their Success]. Wrocław: Wyższa Szkoła Handlowa.

Lisowska, E. (2009). Kobiecy styl zarządzania [Women's Style of Management]. Gliwice: Helion.

Łopusiewicz, A. (2013). Startup. Od pomysłu do sukcesu [Startups. From Idea to Success]. Warsaw: Samo Sedno.

Łukoś, R. (2018). ExMetrix: Liczba startupów w Polsce rzędu ok. 3 tys. to 'poziom nasycenia'. [ExMetrix: The Number of 3.000 Startups in Poland as a 'Level of Saturation']. Retrieved from: https://www.money.pl/gielda/wiadomosci/artykul/ exmetrix-liczba-startupow-w-polsce-rzeduok,91,0,2409307.html.

Moczydłowska, J.M. (2017). Percepcja cech i zachowań osób na stanowiskach kierowniczych przez pryzmat ich płci. [Perception of the Characteristics and Behaviors of people in Managerial Positions Through the Prism of their Gender]. Zarządzanie Zasobami Ludzkimi (3-4), 9-21.

Odpowiedzialne partnerstwo [Responsible partnerships]. 2017-2018, R 9.

Piasecka, A. (2019). Przywództwa kobiet w męskim świecie biznesu [Women leaders in a maledominated Business World]. Benefit (3), 16-17.

Pokonać trudności. [Overcoming Difficulties]. 2017-2018, R 11. 
Rynek pracy, edukacja, kompetencje. Aktualne trendy $i$ wyniki badań. [The Job Market, Education, Competence. Current Trends and Research Results]. PARP, System Rad ds. Kompetencji, Instytut Analiz Rynku Pracy Sp. z o.o., March 2019.

Sarri, K., Trihopoulou, A. (2005). Female entrepreneurs' personal characteristics and motivation: A review of the Greek situation. Women in Management Review 20 (1),

Singh-Cassidy, S. (2015). \#ChoosePossibility Project. Retrieved from: https://medium.com/@ sukhindersinghcassidy/choosepossibility-project90a217ff0a86.

Sperczyński, G. (2014). Przygotowanie do wyceny. Startup okiem praktyka [Preparing for an evaluation. Startups from a practical perspective]. Gliwice: Helion.

Strong women in IT 2019. (2019). Retrieved from: https://strongwomen.comecreationsgroup.pl/ raport-download-403194304031034930341/ Raport-Strong-Women-in-IT-2019.pdf, Come Creations Group.
Sukin, G. (2018). Guild Education Reimagines Employee Benefits to Include Advancement. Retrieved from: https://www.cobizmag.com/ Companies/Guild-Education-ReimaginesEmployee-Benefits-to-Include-Advancement. The 2018 State of European Tech Report is Live. The largest and most comprehensive dataset of European tech is back. (2018). Retrieved from: https://www.atomico.com/the-2018-stateof-european-tech-report-is-live/.

Wainwright, J. (2019). What is the BoF 500? Retrieved from: https://www.businessoffashion. com/community/people/julie-wainwright.

Winn, L. (2019). ClassPass founder Payal Kadakia on how dancing led her to create a multi-million dollar company. Retrieved from: https://abcnews.go.com/Business/classpassfounder-payal-kadakia-passion-danceresulted-million/story?id=60214742. 